\title{
Influence of Lyophilisation and Oven-Drying on Extraction Yield of Oregonin from European Black Alder (AInus glutinosa (L.) Gaertn.) Bark
}

\section{Utjecaj liofilizacije i sušenja u sušioniku na prinos ekstrahiranog oregonina iz kore crne johe (Alnus glutinosa (L.) Gaertn.)}

Original scientific paper • Izvorni znanstveni rad

Received-prispjelo: 2. 12. 2016.

Accepted - prihvaćeno: 30. 8. 2017.

UDK: 630*847; 630*813.25; 674.031.632.154.2

doi:10.5552/drind.2017.1649

\begin{abstract}
Oregonin ((5S)-1,7-bis(3,4-dihydroxyphenyl)-5-( $\beta$-D-xylopyranosyloxy)-heptan-3-one) is the first discovered and reported naturally occurring diarylheptanoid glycoside. It exhibits high biological activity, but it is also the compound of interest because of its ability to form reddish-orange and reddish-brown colours. In this research, European black alder (Alnus glutinosa (L.) Gaertn.) bark was separately subjected to lyophilisation and oven-drying before oregonin extraction with two different solvents. According to the results, methanol has proven to be more suitable as solvent compared to deionised water for oregonin extraction by maceration from black alder bark matrix regardless of the dehydration method. Accordingly, in the case of methanol, much higher yields of oregonin were obtained after lyophilisation, than after oven-drying. Furthermore, extraction by deionised water produced slightly higher yield of oregonin after oven-drying than after lyophilisation, as opposed to methanol. However, in much lower oregonin concentrations. Among other things, oregonin propensity to degradation at elevated temperature could probably be applied for improving and facilitating alder wood hydrothermal processing by minimizing uneven discolouration.
\end{abstract}

Keywords: European black alder, bark, oregonin, hydrothermal treatment, lyophilisation (freeze-drying), ovendrying, extraction yield, methanol, deionised water

SAŽETAK • Oregonin ((5S)-1,7-bis(3,4-dihidroksifenil)-5-( $\beta$-D-ksilopiranosiloksi)-heptan-3-on) prvi je otkriveni i objavljeni prirodni diarilheptanoid glikozid. Pokazuje visoku biološku aktivnost, a važan je i zbog svoje sposobnosti da stvara crvenonarančaste i crvenosmeđe boje. U ovom je istraživanju kora europske crne johe (Alnus

\footnotetext{
${ }^{1}$ Authors are postdoctoral researcher and professor at the University of Zagreb, Faculty of Forestry, Wood Technology Department, Zagreb, Republic of Croatia. ${ }^{2}$ Author is postdoctoral researcher at the University of Zagreb, Faculty of Chemical Engineering and Technology, Department of Analytical Chemistry, Zagreb, Republic of Croatia.

${ }^{1}$ Autori su poslijedoktorand i profesor Sveučilišta u Zagrebu, Šumarski fakultet, Drvnotehnološki odsjek, Zagreb, Republika Hrvatska. ${ }^{2} \mathrm{Au}-$ torica je poslijedoktorandica Sveučilišta u Zagrebu, Fakultet kemijskog inženjerstva i tehnologije, Zavod za analitičku kemiju, Zagreb, Republika Hrvatska.
} 
glutinosa (L.) Gaertn.) zasebno podvrgnuta liofilizaciji i sušenju u sušioniku prije ekstrakcije oregonina dvama različitim otapalima. Prema dobivenim rezultatima, pokazalo se da je za ekstrakciju oregonina maceracijom iz matrice kore crne johe prikladnije otapalo metanol nego deionizirana voda, bez obzira na primijenjenu dehidracijsku metodu. U skladu s navedenim, upotrebom metanola ostvareni su mnogo viši prinosi oregonina nakon liofilizacije nego nakon sušenja u sušioniku. Za razliku od metanola, pri ekstrakciji deioniziranom vodom prinosi oregonina nešto su veći nakon sušenja u sušioniku nego poslije liofilizacije, ali su njegove koncentracije znatno niže. Među ostalim, sklonost oregonina degradaciji pri povišenoj temperaturi vjerojatno bi se mogla iskoristiti za poboljšanje i olakšanje hidrotermičke obrade crne johe minimalizacijom neravnomjerne promjene boje.

Ključne riječi: europska crna joha, kora, oregonin, hidrotermička obrada, liofilizacija, sušenje u sušioniku, prinos ekstrakcije, metanol, deionizirana voda

\section{INTRODUCTION}

\section{UVOD}

Oregonin ((5S)-1,7-bis(3,4-dihydroxyphenyl)-5( $\beta$-D-xylopyranosyloxy)-heptan-3-one) is the first discovered and reported naturally occurring diarylheptanoid glycoside (Karchesy et al., 1974), and afterwards its "S" absolute configuration was determined combining ${ }^{13} \mathrm{C}$ NMR spectroscopy and the $\mathrm{X}$-ray crystallography (Suga et al., 1982). Considering its structure, oregonin belongs to a class of linear 1,7-diarylheptanoids, natural phenolic compounds, which constitute a separate small group of plant metabolites characterized by two aromatic rings connected with seven carbon chain $\left(\mathrm{C}_{6}-\mathrm{C}_{7}-\mathrm{C}_{6}\right)$.

In the previous papers of other researchers, oregonin has been isolated and reported from the bark of several alder species (Alnus spp.) (Table 1). Its biological activity was reported together with its anti-oxidant, anti-inflammatory, anti-microbial, anti-atopic dermatitis, and anti-cancer properties (Kuo et al., 2008; Choi et al., 2010; Tung et al., 2010; Sati et al., 2011; Telysheva et al., 2011). Therefore, black alder bark could be used as a resource of bioactive compounds, and not only as fuel in wood processing companies as currently used. Besides exhibiting high biological activity, oregonin is also the compound of interest because of its ability to form reddish-orange and reddish-brown colours, which particularly affects alder wood hydrothermal processing.

Among other factors, heat can have negative influence on bioactive compounds during their acquisition and chemical analysis. On the other hand, however, heat could be used for inactivation of chemical compounds (if prone to thermal degradation) that impede hydrothermal wood processing. As for the lyophilisation process, there is an unwarranted and unexamined assumption<smiles>O=C(CCc1ccc(O)c(O)c1)C[C@H](CCc1ccc(O)c(O)c1)O[C@@H]1OCC(O)[C@H](O)[C@H]1O</smiles>

Figure 1 Chemical structure of Oregonin Slika 1. Kemijska struktura oregonina
Table 1 Alder species (Alnus spp.) in which oregonin presence in bark was reported

Tablica 1. Vrste johe (Alnus spp.) u kojima je utvrđeno postojanje oregonina u kori

\begin{tabular}{|l|l|}
\hline \multicolumn{1}{|c|}{ Species / Vrsta } & \multicolumn{1}{c|}{ Source / Izvor } \\
\hline $\begin{array}{l}\text { Alnus glutinosa (L.) } \\
\text { Gaertn. }\end{array}$ & $\begin{array}{l}\text { Guz et al., 2002; Roze et al., } \\
\text { 2011; Novaković et al., 2013 }\end{array}$ \\
\hline Alnus incana (L.) Moench & $\begin{array}{l}\text { Guz et al., 2002; Roze et al., } \\
\text { 2011; Telysheva et al., 2011 }\end{array}$ \\
\hline Alnus rubra Bong. & Karchesy et al., 1974 \\
\hline Alnus viridis (Chaix) D.C. & Guz et al., 2002 \\
\hline $\begin{array}{l}\text { Alnus cordata (Loisel.) } \\
\text { Duby }\end{array}$ & Guz et al., 2002 \\
\hline Alnus hirsuita var. sibirica & Lee et al., 2000 \\
\hline $\begin{array}{l}\text { Alnus japonica } \text { (Thunb.) } \\
\text { Steud. }\end{array}$ & Baek et al., 2011 \\
\hline Alnus pendula Matsum. & Choi, 2013 \\
\hline Alnus tinctoria Sarg. & Ko et al., 2015 \\
\hline
\end{tabular}

that it properly and optimally preserves the plant constituents, but these assumptions may be erroneous in some cases (Abascal et al., 2005). In this research, the influence of heat and dehydration procedure on oregonin extraction yield from black alder bark was investigated and reported. Bark was used instead of wood because it contains larger quantities of oregonin than wood (Klarić, 2015). The stated research results will help understanding the influence of lyophilisation on oregonin extraction yield as compared to oven-drying. Furthermore, methanol and deionised water were compared as solvents for the oregonin extraction.

\section{MATERIAL AND METHODS} 2. MATERIJAL I METODE

\subsection{Chemicals}

2.1. Kemikalije

High purity ( $\geq 95 \%$ ) analytical standard of oregonin was obtained from Sigma-Aldrich (Germany). For the extraction process, methanol (MeOH) of HPLC grade was supplied by J. T. Baker (USA), while deionized water $\left(\mathrm{dH}_{2} \mathrm{O}\right)$ (ASTM Type II) was prepared on TKA/Thermo Scientific MicroMed Pure system (Thermo Fisher Scientific, USA). Formic acid of analytical grade (Orka Lab, Croatia) and deionised water (ASTM Type I, (MiliQ)) prepared on Millipore Simplicity Purification system (Millipore Corporation, USA) were used for mobile phase in high performance liquid chromatography (HPLC) analysis. 


\subsection{Bark acquisition and preparation}

\subsection{Dobivanje i priprema kore}

Bark (inner \& outer bark included) was collected from five-centimetre thick cross-section segment (disk) sawn at the height of 1.5 meters (from the ground) from black alder tree (30 cm breast height diameter). The tree was sampled during July 2014 in thirty-year old forest department " 98 " section "b" within the management unit "Đurđevačke nizinske šume” owned and governed by the Croatian state forest enterprise Hrvatske šume Ltd. The bark sample was milled and homogenized according to the previously described procedure (Klarić et al., 2016). A certain amount of frozen homogenized raw bark was oven-dried at $103 \pm 2{ }^{\circ} \mathrm{C}$ till constant mass has been reached. Another amount of frozen homogenized raw bark was lyophilised (Christ alpha 1-2 LD, Germany) by the main drying phase (-55 ${ }^{\circ} \mathrm{C}, 0.021$ bar, 24 hours) and final drying phase (-50 ${ }^{\circ} \mathrm{C}, 0.040$ bar, 4 hours).

\subsection{Extraction procedure}

\subsection{Ekstrakcija}

Extraction by maceration was conducted on magnetic stirrer (IKA C-MAG HS 7, Germany) for 24 hours (mot 1.5) at $20 \pm 1{ }^{\circ} \mathrm{C}$. Two grams of oven-dried and lyophilized bark were separately extracted in 250 $\mathrm{mL}$ of $\mathrm{MeOH}$ and $\mathrm{dH}_{2} \mathrm{O}$, in triplicates with regard to solvent type and dehydration procedure. The obtained extracts were filtered through grade 388 quantitative ashless filter paper (Munktell, Sweden), and stored in amber glass jars and kept in refrigerator till further analysis. Before HPLC analysis, extracts were additionally filtered through syringe nylon filters $(0.22 \mu \mathrm{m})$ in amber glass vials with rubber/FEP sept. The amount of extracted oregonin from bark was determined by HPLC-DAD method.

\subsection{Liquid chromatography}

\subsection{Tekućinska kromatografija}

The liquid chromatography analysis was conducted using a Varian ProStar 500 (USA) HPLC system consisting of a ProStar 330 diode array detector (DAD), ProStar 410 autosampler, ProStar 230 tertiary pump system and column compartment. Instrument control, data acquisition and evaluation were done with Star Chromatography Work station v5.5 (Varian ProStar 360). Separation was performed on Nucleosil-C18 column $150 \times 4.6 \mathrm{~mm}$, particle size $5 \mu \mathrm{m}$ (Supelco Analytical, USA). The analysis was performed using
$0.1 \%$ formic acid in $\mathrm{MeOH}$ as eluent $\mathrm{A}$ and $0.1 \%$ formic acid in MiliQ water as eluent B in gradient elution mode. The elution started with $90 \%$ of eluent B for 25 min, following 25 min gradient to $0 \%$ of B and then back to initial conditions within 5 min. Flow rate was $0.5 \mathrm{~mL} \cdot \mathrm{min}^{-1}$ and injection volume was $10 \mu \mathrm{L}$. The separation was monitored at absorbance wavelength of $280 \mathrm{~nm}$. Stock standard solution of oregonin was prepared by dissolving accurate quantity of the standard in $\mathrm{MeOH}$ and stored in the dark at $4{ }^{\circ} \mathrm{C}$. The working standard solutions of different concentrations were prepared by appropriate dilution of the stock solution. Calibration curve for oregonin was prepared using six working standard solutions in the range $5-100 \mathrm{mg} \cdot \mathrm{L}^{-1}$ (5, 20, 40, 60, 80 and $\left.100 \mathrm{mg} \cdot \mathrm{L}^{-1}\right)$. The calibration curve was plotted from chromatograms as peak area vs. concentration of the standard. For each extract, three separate vials were prepared.

\subsection{Statistical analysis}

2.5. Statistička analiza

Along with descriptive statistics, Welch's ANOVA compared means test was conducted at the 0.05 significance level. STATISTICA 12 Dell Inc., and MS Excel software were used.

\section{RESULTS AND DISCUSSION} 3. REZULTATI I RASPRAVA

In this research, the effect of lyophilisation and oven-drying on maceration extraction yield of oregonin with $\mathrm{MeOH}$ and $\mathrm{dH}_{2} \mathrm{O}$ was investigated. The amount of extracted oregonin was determined by HPLC-DAD analysis. To confirm the presence of the target compound in bark samples, retention time of peak obtained by analysing extracts of bark were compared with retention time of standard compound. Further, confirmation of peak identity was provided by comparison of UV spectra obtained by DAD. Strong agreement of retention time $\left(t_{\mathrm{R}}=16.50 \mathrm{~min}\right)$ and $\mathrm{UV}$ spectra $\left(\lambda_{\text {max }}=280 \mathrm{~nm}\right)$ from oregonin standard and peak from bark extracts were obtained, thus confirming the identity of target analyte. The chromatogram of oregonin is shown in Figure 2. The quantification of oregonin was carried out on the basis of the calibration curve $(y=5.8621 \cdot x-2.322)$. Coefficient of determination $\left(R^{2}\right)$ was 0.9993 confirming high degree of correlation and good linearity of the method. Acceptable RSD values were obtained, $0.4 \%$ for repeatability and

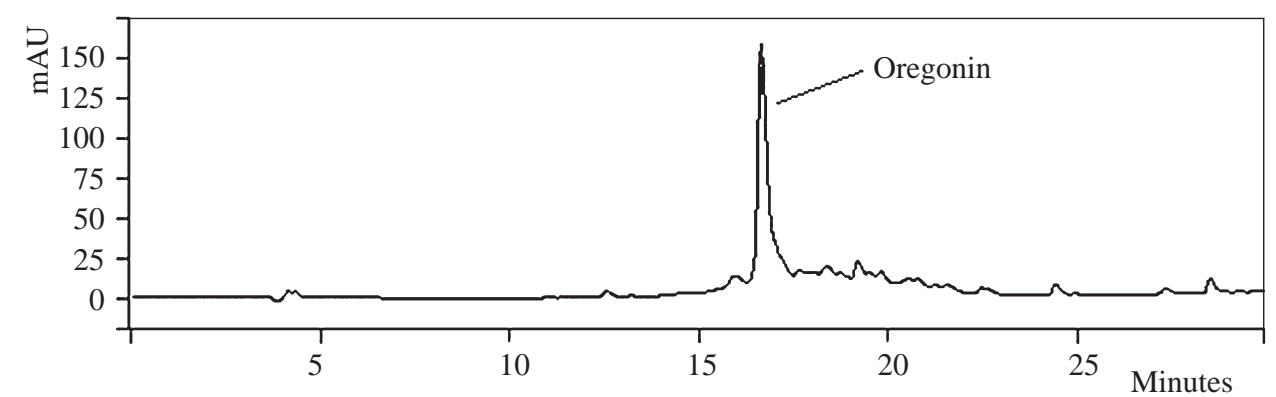

Figure 2 Chromatogram of oregonin obtained with $\mathrm{MeOH}$ after lyophilisation Slika 2. Kromatogram oregonina dobiven uz pomoć MeOH nakon liofilizacije 
Table 2 Average content of oregonin, descriptive statistic, $\mathrm{mg} \cdot \mathrm{g}_{\mathrm{dm}}{ }^{-1}$

Tablica 2. Prosječni sadržaj oregonina, deskriptivna statistika, $\mathrm{mg} \cdot \mathrm{g}_{\mathrm{dm}}{ }^{-1}$

\begin{tabular}{|c|c|c|c|c|c|c|c|c|c|c|}
\hline$S$ & $D$ & $E$ & $N$ & Mean & $S D$ & $95 C I$ & Med & $I Q R$ & MIN & MAX \\
\hline \multirow{6}{*}{ 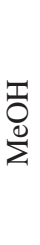 } & \multirow{3}{*}{ 今 } & I & 3 & 60.63 & 0.20 & $60.144-61.121$ & 60.53 & 0.35 & 60.51 & 60.86 \\
\hline & & II & 3 & 58.21 & 0.34 & $57.380-59.047$ & 58.03 & 0.59 & 58.01 & 58.60 \\
\hline & & III & 3 & 60.25 & 0.58 & $58.818-61.688$ & 60.42 & 1.12 & 59.61 & 60.73 \\
\hline & \multirow{3}{*}{$\stackrel{\circ}{\circ}$} & $\mathrm{I}$ & 3 & 7.71 & 0.09 & $7.489-7.929$ & 7.69 & 0.18 & 7.63 & 7.80 \\
\hline & & II & 3 & 7.72 & 0.10 & $7.479-7.954$ & 7.67 & 0.18 & 7.65 & 7.83 \\
\hline & & III & 3 & 7.53 & 0.17 & $7.122-7.946$ & 7.61 & 0.31 & 7.34 & 7.65 \\
\hline \multirow{6}{*}{$\begin{array}{l}O_{N} \\
\underline{\Xi}^{\prime}\end{array}$} & \multirow{3}{*}{ ふ } & I & 3 & 1.26 & 0.04 & $1.163-1.364$ & 1.26 & 0.08 & 1.22 & 1.30 \\
\hline & & II & 3 & 1.25 & 0.08 & $1.058-1.434$ & 1.28 & 0.14 & 1.16 & 1.30 \\
\hline & & III & 3 & 1.21 & 0.04 & $1.110-1.300$ & 1.22 & 0.07 & 1.16 & 1.23 \\
\hline & \multirow{3}{*}{$\stackrel{9}{\circ}$} & I & 3 & 4.12 & 0.04 & $4.012-4.230$ & 4.12 & 0.09 & 4.08 & 4.17 \\
\hline & & II & 3 & 4.22 & 0.06 & $4.079-4.353$ & 4.21 & 0.11 & 4.17 & 4.27 \\
\hline & & III & 3 & 4.10 & 0.04 & $3.991-4.208$ & 4.10 & 0.09 & 4.06 & 4.14 \\
\hline
\end{tabular}

Note: $S$ - type of solvent / vrsta otapala; D - type of dehydration / vrsta dehidracije; Lyo. - lyophilisation / liofilizacija; O.D. - oven-drying at $103 \pm 2{ }^{\circ} \mathrm{C} /$ sušenje u sušioniku pri $103 \pm 2{ }^{\circ} \mathrm{C} ; \mathrm{E}$ - extraction process / proces ekstrakcije; $N$ - number of measurements / broj mjerenja; Mean - arithmetic mean / aritmeticka sredina; SD - standard deviation / standardna devijacija; 95 CI - 95 \% confidence interval of the mean / 95 \%-tni interval pouzdanosti; Med - median / medijan; IQR - interquartile range / interkvartilni raspon; MIN - minimum value / minimalna vrijednost; $M A X$ - maximum value / maksimalna vrijednost

$1.4 \%$ for reproducibility. Extracts of oregonin from bark were analysed and expressed as mg of oregonin per $g$ of dry bark mass. The descriptive results of the research are shown in Table 2.

As it is evident from the presented results (Table 2), statistically significant difference for oregonin yields was established between dehydration methods for $\mathrm{MeOH}(F(1,8.220=17297.271, p<0.001)$, and for $\mathrm{dH}_{2} \mathrm{O}(F(1,15.191)=10136.376, p<0.001)$. A statistically significant difference was also observed in oregonin yields between $\mathrm{MeOH}$ and $\mathrm{dH}_{2} \mathrm{O}$ after lyophilisation $(F(1,8.033)=22078.953, p<0.001)$, and after oven-drying $(F(1,11.646)=4657.159, p<0.001)$, as determined by Welch's ANOVA. With methanol, much higher yields of oregonin from black alder bark were obtained after lyophilisation than after oven-drying at $103 \pm 2{ }^{\circ} \mathrm{C}$. However, in case of $\mathrm{dH}_{2} \mathrm{O}$, this trend is reversed. This reversed trend in the case of $\mathrm{dH}_{2} \mathrm{O}$ was unexpected, but regardless of dehydration method applied, much higher oregonin yield was obtained with $\mathrm{MeOH}$ than with $\mathrm{dH}_{2} \mathrm{O}$ as a solvent. During the dehydration process, changes that take place within wood are dependent on time-temperature-moisture-oxygen interrelationship (Navi and Sandberg, 2012). Consequently, in specific cases, the degradation of compounds present in wood and/or formation of newly formed compounds is possible, due to a wide range of

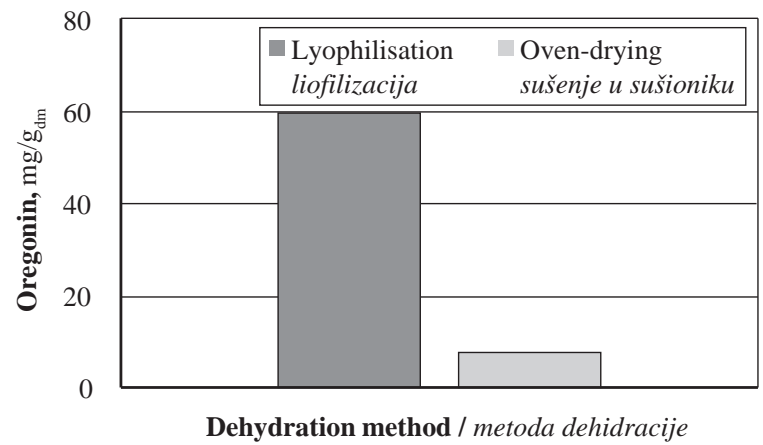

Figure 3 Oregonin average content $-\mathrm{MeOH}$

Slika 3. Prosječni sadržaj oregonina - $\mathrm{MeOH}$ chemical reactions, such as oxidation, hydrolysis, deacetylation, depolymerisation, etc. (Hon and Minemura, 2001; Fengel and Wegener, 2003; Hill, 2006; Navi and Sandberg, 2012; Németh et al., 2013). Although it is generally considered that the lyophilisation is a preferable dehydration method, which retains higher levels of phenols i.e. bioactive compounds in the sample, it may not always be the case (Abascal et al., 2005; Dai and Mumper, 2010; Jiang et al., 2016). As regards VOCs (volatile organic compounds), they are probably lost to a greater extent during lyophilisation, as opposed to other dehydration methods at lower temperatures during which no vacuum is applied, or if fresh plant material is used (Abascal et al., 2005). In addition to low temperatures, another important advantage of lyophilisation during the acquisition of natural bioactive compounds is that the sample oxidation is prevented during dehydration process due to the lack of oxygen, considering bark and wood great internal structural voids and hygroscopicity of structural components of the matrix. On the other hand, if an elevated temperature near $100{ }^{\circ} \mathrm{C}$ is applied, catechol oxidases will most likely be inactivated, i.e. subjected to denaturation causing the loss of activity. This inactivation of the enzymes can then facilitate the successful implementation of wood hydrothermal processing. As regards methanol, it is often a solvent of choice for ex-

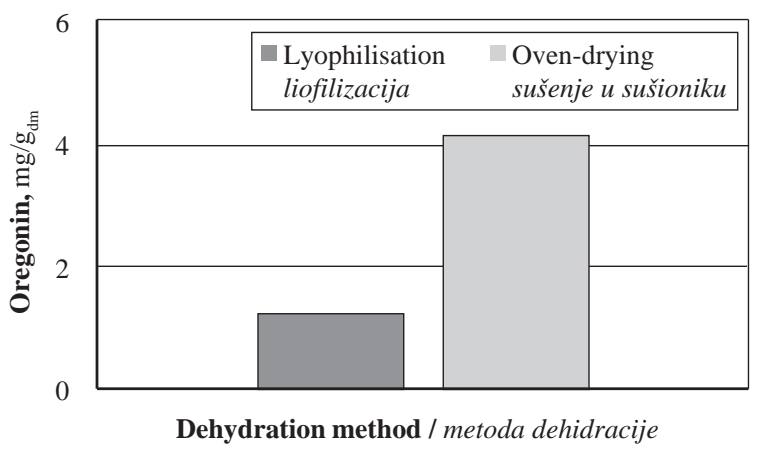

Figure 4 Oregonin average content $-\mathrm{dH}_{2} \mathrm{O}$

Slika 4. Prosječni sadržaj oregonina $-\mathrm{dH}_{2} \mathrm{O}$ 
traction of phenols from plant material. Comparing several organic solvents and deionised water, Klarić et al. (2016) established that $\mathrm{MeOH}$ produce highest yields of total soluble extractives (TSEs), phenols (TSPs) and flavonoids (TSFs) from black alder bark and wood. Presumably, additional improvements of oregonin extraction yields with $\mathrm{MeOH}$ could most likely be achieved by mixing $\mathrm{MeOH}$ with smaller portions of $\mathrm{dH}_{2} \mathrm{O}$ (Fang et al., 2013). Also, if slightly higher extraction temperature was employed, the oregonin yield with $\mathrm{dH}_{2} \mathrm{O}$ would probably be somewhat higher, due to surface tension and viscosity reduction, thus facilitating $\mathrm{dH}_{2} \mathrm{O}$ penetration into the bark matrix (Dai and Mumper, 2010; Fang et al., 2013). Additional advantage of $\mathrm{MeOH}$, compared to $\mathrm{dH}_{2} \mathrm{O}$, is that enzymes (in this case catechol oxidase) present in the plant will be deactivated (Jones and Kinghorn, 2006), and that fungi development will be prevented. Figure 3 and Figure 4 show the combined $\mathrm{MeOH}$ and $\mathrm{dH}_{2} \mathrm{O}$ oregonin average yields after lyophilisation and oven-drying.

Further research regarding oregonin will be focused on its presence, concentration and influence on black alder wood discolouration during hydrothermal processing.

\section{CONCLUSION}

\section{ZAKLJUČAK}

It is more preferable to use $\mathrm{MeOH}$ as a solvent for oregonin extraction by maceration from black alder bark than $\mathrm{dH}_{2} \mathrm{O}$, regardless of the applied dehydration method. According to the obtained results, the highest yields of oregonin were achieved by conducting extraction with $\mathrm{MeOH}$ after lyophilisation, while significantly lower yields were achieved after oven-drying at $103 \pm 2{ }^{\circ} \mathrm{C}$. On the basis of the above mentioned findings, it could be concluded that, among others, oregonin is presumably prone to degradation at elevated temperature (103 $\left.\pm 2{ }^{\circ} \mathrm{C}\right)$. This finding could probably be implemented in hydrothermal wood processing to minimize the uneven discolouration of wood by conducting pre-steaming or similar high temperature procedures immediately after sawing and before kiln drying. If oregonin is the compound of interest because of its high biological activity, lyophilisation should be a preferred method of dehydration, accompanied by a suitable extraction solvent.

In the case of $\mathrm{dH}_{2} \mathrm{O}$, yields of oregonin obtained after lyophilisation and oven-drying were reversed compared to $\mathrm{MeOH}$ as can be seen in Figure 3 and Figure 4. This reversed trend in the case of $\mathrm{dH}_{2} \mathrm{O}$ is an interesting and unexpected phenomenon that should be further researched.

\section{REFERENCES}

5. LITERATURA

1. Abascal, K.; Ganora, L.; Yarnell, E., 2005: The Effect of Freeze-drying and its Implications for Botanical Medicine: A Review. Phytotherapy Research, 19 (8): 655-660. https://doi.org/10.1002/ptr.1651.
2. Baek, J.-S.; Kang, H.-C.; Keum, C.-G.; Lim, J.-H.; Hwang, C.-J.; Na, Y.-G.; Tung, N. H.; Kim, Y.-H.; Cho, C.-W, 2011: Quantitative Analysis and Preformulation of Extracts from Alnus Japonica. Journal of Pharmaceutical Investigation, 41 (4): 227-232. https://doi.org/10.4333/KPS.2011.41.4.227.

3. Choi, S. E., 2013: Chemotaxonomic Significance of Oregonin in Alnus Species, Asian Journal of Chemistry, 25 (12): 6989-6990. https://doi.org/10.14233/ajchem.2013.15090.

4. Choi, S. E.; Jeong, M. S.; Kang, M. J.; Lee, D. I.; Joo, S. S.; Lee, C. S.; Bang, H.; Lee, M.-K.; Myung, S.-C.; Choi, Y. W.; Li, K.; Seo, S. J.; Lee, M. W., 2010: Effect of Topical Application and Intraperitoneal Injection of Oregonin on Atopic Dermatitis in NC/Nga Mice. Experimental dermatology, 19 (8): e37-e43. https://doi.org/10.1111/j.1600-0625.2009.00961.x.

5. Dai, J.; Mumper, R. J., 2010: Plant Phenolics: Extraction, Analysis and Their Antioxidant and Anticancer Properties. Molecules, 15 (10): 7313-7352. https://doi.org/10.3390/molecules15107313.

6. Fang, W.; Hemming, J.; Reunanen, M.; Eklund, P.; Conde Pineiro, E.; Poljanšek, I.; Oven, P.; Willför, S., 2013: Evaluation of Selective Extraction Methods for Recovery of Polyphenols from Pine. Holzforschung, 67 (8): 843-851. https://doi.org/10.1515/hf-2013-0002.

7. Fengel, D.; Wegener, G., 2003: Wood. Chemistry, Ultrastructure, Reactions. Verlag Kessel, Remagen, Germany, $613 \mathrm{pp}$.

8. Guz, N. R.; Lorenz, P.; Métraux, J.-P., 2002: Oregonin from the Bark of European Alnus Species. Biochemical Systematics and Ecology, 30 (5): 471-474. https://doi.org/10.1016/S0305-1978(01)00084-9.

9. Hill, C., 2006: Wood Modification. Chemical, Thermal and Other Processes. John Wiley \& Sons Ltd., 239 pp. https://doi.org/10.1002/0470021748.

10. Hon, D. N. -S.; Minemura, N., 2001: Color and Discoloration. In "Wood and Cellulosic Chemistry" second edition, revised and expanded, ed. D. N.-S. Hon and N. Shiraishi, Marcel Dekker Inc., p.p. 385-442.

11. Jiang, T.; Li, K.; Liu, H.; Yang, L., 2016: The Effects of Drying Methods on Extract of Dalbergia cochinchinensis Pierre. European Journal of Wood and Wood Products, 74 (5): 663-669. https://doi.org/10.1007/s00107-016-1041-2.

12. Jones, W. P.; Kinghorn, A. D., 2006: Extraction of Plant Secondary Metabolites. In "Methods in Biotechnology, Vol. 20, Natural Products Isolation ( $2^{\text {nd }}$ edition)", ed. S. D. Sarker, Z. Latif and A. I. Gray, Humana Press Inc., p.p. 323-351. https://doi.org/10.1385/1-59259-955-9:323.

13. Karchesy, J. J.; Laver, M. L.; Barofsky, D. F.; Barofsky, E., 1974: Structure of Oregonin, a Natural Diarylheptanoid Xyloside. Journal of the Chemical Society, Chemical Communications, (16): 649-650. https://doi.org/10.1039/c39740000649.

14. Klarić, M., 2015: Identifikacija i karakterizacija činitelja promjene boje drva crne johe (Alnus glutinosa (L.) Garetn.) tijekom hidrotermičkih procesa. $\mathrm{PhD}$ thesis, University of Zagreb, Faculty of Forestry.

15. Klarić, M.; Oven, P.; Gorišek, Ž.; Španić, N.; Pervan, S., 2016: Yield of Stirred Cold Maceration and Extraction of Milled European Black Alder Wood and Bark using Different Solvents. BioResources, 11 (4): 9244-9254. https://doi.org/10.15376/biores.11.4.9244-9254.

16. Ko, E.-K.; Choi, H.-N.; Jin, H.-Y.; Choi, S.-E., 2015: Oregonin from the Stems and Leaves of Korean Alnus Species (Betulaceae), Journal of Chemical and Pharmaceutical Research, 7 (4): 234-238. 
17. Kuo, C.-H.; Lee, C.-W.; Lai, Y.-C.; Lee, S.-S., 2008: Determination of oregonin in Alnus plants and biological samples by capillary electrophoresis. Journal of Pharmaceutical and Biomedical Analysis, 47 (1): 195-200. https://doi.org/10.1016/j.jpba.2007.12.012.

18. Lee, M.-W.; Kim, J.-H.; Jeong, D.-W.; Ahn, K.-H.; Toh, S.-H.; Surh, Y.-J., 2000: Inhibition of Cyclooxygenase-2 Expression by Diarylheptanoids from the Bark of Alnus hirsuita var. sibirica. Biological \& Pharmaceutical Bulletin, 23 (4): 517-518. https://doi.org/10.1248/bpb.23.517.

19. Navi, P.; Sandberg, D., 2012: Thermo-Hydro-Mechanical Processing of Wood. EPFL Press, Switzerland, 360 pp.

20. Németh, R.; Ott, Á.; Takáts, P.; Bak, M., 2013: The Effect of Moisture Content and Drying Temperature on the Colour of Two Poplars and Robinia Wood. BioResources, 8 (2): 2074-2083. https://doi.org/10.15376/biores.8.2.2074-2083.

21. Novaković, M.; Stanković, M.; Vučković, I.; Todorović, N.; Trifunović, S.; Tešević, V.; Vajs, V.; Milosavljević, S., 2013: Diarylheptanoids from Alnus glutinosa Bark and Their Chemoprotective Effect on Human Lymphocytes DNA. Planta Medica, 79 (06): 499-505. https://doi.org/10.1055/s-0032-1328301.

22. Roze, L.; Bikovens, O.; Telysheva, G., 2011: Determination and Separation of Diarylheptanoids from Alder Growing in Latvia. Environment, Technology, Resources, Proceedings of the $8^{\text {th }}$ International Scientific and Practical Conference. Volume 1, p.p. 329-332. https://doi.org/10.17770/etr2011vol1.916.

23. Sati, S. C.; Sati, N.; Sati, O. P., 2011: Bioactive Constituents and Medicinal Importance of Genus Alnus. Pharmacognosy Reviews, 5 (10): 174-183. https://doi.org/10.4103/0973-7847.91115.
24. Suga, T.; Ohta, S.; Hirata, T.; Aoki, T., 1982: The Absolute Configuration of Diarylheptanoid Xyloside, Oregonin, Isolated from the Female Flowers of Alnus serrulatoides. Chemistry Letters, 11 (6): 895-898. https://doi.org/10.1246/cl.1982.895.

25. Telysheva, G.; Dizhbite, T.; Bikovens, O.; Ponomarenko, J.; Janceva, S.; Krasilnikova, J., 2011: Structure and Antioxidant Activity of Diarylheptanoids Extracted from Bark of Grey Alder (Alnus incana) and Potential of Biorefinery-based Bark Processing of European Trees. Holzforschung, 65 (4): 623-629. https://doi.org/10.1515/hf.2011.096.

26. Tung, N. H.; Kwon, H.-J.; Kim, J.-H.; Ra, J. C.; Ding, Y.; Kim, J. A.; Kim, Y. H., 2010: Anti-influenza Diarylheptanoids from the Bark of Alnus japonica. Bioorganic \& Medicinal Chemistry Letters, 20 (3): 1000-1003. https://doi.org/10.1016/j.bmcl.2009.12.057.

\section{Corresponding address:}

Prof. STJEPAN PERVAN, Ph. D.

University of Zagreb, Faculty of Forestry Wood Technology Department Svetošimunska 25, p.p. 422 HR-10002 Zagreb, REPUBLIC OF CROATIA e-mail: spervan@sumfak.hr 